\title{
Prolactin, the prolactin receptor and uncoupling protein abundance and function in adipose tissue during development in young sheep
}

\author{
S Pearce, H Budge, A Mostyn, E Genever, R Webb ${ }^{1}$, P Ingleton ${ }^{2}$, \\ A M Walker ${ }^{3}$, M E Symonds and T Stephenson \\ Centre for Reproduction and Early Life, Institute of Clinical Research, Queen's Medical Centre, University Hospital, Nottingham, NG7 2UH, UK \\ ${ }^{1}$ Division of Agricultural Sciences, School of Biosciences, University of Nottingham, Sutton Bonington Campus, Loughborough, LE12 5RD, UK \\ ${ }^{2}$ Division of Biochemical and Musculoskeletal Medicine, Human Metabolism and Clinical Biochemistry, University of Sheffield Medical School, \\ Sheffield S10 2RX, UK \\ ${ }^{3}$ Division of Biomedical Sciences, University of California, Riverside, California, 92521, USA \\ (Requests for offprints should be addressed to H Budge, Academic Division of Child Health, Queen's Medical Centre, University Hospital, \\ Nottingham NG7 2UH, UK; Email: Helen.Budge@nottingham.ac.uk)
}

\begin{abstract}
A primary role of the prolactin receptor (PRLR) during fetal and postnatal development has been suggested to be the regulation of uncoupling protein (UCP) expression. We, therefore, determined whether: (1) the rate of loss of UCP1 from brown adipose tissue after birth was paralleled by the disappearance of PRLR; and (2) administration of either pituitary extract prolactin (PRL) containing a mixture of posttranslationally modified forms or its pseudophosphorylated form (S179D PRL) improved thermoregulation and UCP1 function over the first week of neonatal life. PRLR abundance was greatest in adipose tissue $6 \mathrm{~h}$ after birth before declining up to 30 days of age, a trend mirrored by first a gain and then a loss of UCP1. In contrast, in the liver - which does not possess UCPs -
\end{abstract}

a postnatal decline in PRLR was not observed. Administration of PRL resulted in an acute increase in colonic temperature in conjunction with increased plasma concentrations of non-esterified fatty acids and, as a result, the normal postnatal decline in body temperature was delayed. S179D PRL at lower concentrations resulted in a transient rise in colonic temperature at both 2 and 6 days of age. In conclusion, we have demonstrated a close relationship between the ontogeny of UCP1 and the PRLR. Exogenous PRL administration elicits a thermogenic effect suggesting an important role for the PRLR in regulating UCP1 function.

Journal of Endocrinology (2005) 184, 351-359

\section{Introduction}

During late gestation, ovine fetal prolactin (PRL) secretion is maintained by a tonic stimulatory, rather than inhibitory, drive from the hypothalamus (Houghton et al. 1995, McMillen et al. 2001). Plasma PRL increases with gestational age and concentrations peak around the time of birth at between 20 and $150 \mathrm{ng} / \mathrm{ml}$ depending in part on the photoperiodic history of the fetus (Bassett et al. 1989, Phillips et al. 1999). PRL, acting through its receptors (PRLRs), has a diverse range of functions in the adult including the control of reproduction, lactation and wool growth (Goffin et al. 1999). The role of PRL in the fetus and neonate has yet to be established. Both mRNA and protein for the PRLRs are highly abundant in fetal and neonatal brown adipose tissue (Symonds et al. 1998, Bispham et al. 1999). Growth of fetal fat occurs primarily over the second half of gestation when there is a marked rise in abundance of PRLR mRNA (Symonds et al. 1998) preceding the rise in the abundance of the brown adipose tissue-specific mitochondrial protein, uncoupling protein (UCP)1 (Clarke et al. 1997a) immediately after birth. Rapid activation of UCP1 in the newborn is critical in preventing hypothermia (Clarke et al. 1997c). Previous studies in rats have shown that maternal administration of native PRL or a recombinant molecular mimic of phosphorylated PRL (S179D PRL) throughout gestation promotes brown adipose tissue development and function in the fetus (Yang et al. 2001, Budge et al. 2002). This effect is probably a result of the direct transfer of exogenous PRL from the mother to the fetus (Yang et al. 2002) and suggests a stimulatory role for PRL in the maturation of brown fat. The extent to which comparable effects may be observed after birth in a species with a mature hypothalamic-pituitary axis is not known.

Over the first few weeks of life, UCP1 is lost as adipose tissue adopts the characteristics of white fat and the neonate has become reliant on shivering thermogenesis (Symonds et al. 1989, Clarke et al. 1997b). It is not known whether this disappearance of UCP1 is accompanied by a 
Table 1 Summary of animal numbers and experimental protocols

\begin{tabular}{|c|c|c|c|c|}
\hline & \multirow{2}{*}{$\begin{array}{l}\text { Duration of } \\
\text { experiment } \\
\text { (days) }\end{array}$} & \multirow{2}{*}{$\begin{array}{l}\text { Animal age at } \\
\text { tissue sampling } \\
\text { (days) }\end{array}$} & \multicolumn{2}{|c|}{ Animal numbers } \\
\hline & & & PRL & Control \\
\hline \multicolumn{5}{|l|}{$\begin{array}{l}\text { Form of PRL } \\
\text { administered }\end{array}$} \\
\hline Native PRL & 1 & 1 & 7 & 7 \\
\hline Native PRL & 6 & 7 & 8 & 8 \\
\hline S179D PRL & 6 & 7 & 6 & 6 \\
\hline S179D PRL & 6 & 28 & 3 & 3 \\
\hline
\end{tabular}

parallel loss of PRLRs. The PRLR is expressed as both long and short varieties, which result from differential splicing of a single gene transcript (Bignon et al. 1997). These splice variants differ in their intracellular signalling regions, but have identical extracellular domains. In addition, studies using antibodies directed against the specific intracellular region of each splice variant have been found to detect a number of proteolytically processed forms of each kind of receptor (Nevalainen et al. 1996, Budge et al. 2000). In this study, we have determined whether the postnatal loss of UCP1 is correlated with a tissue-specific parallel decline in PRLR abundance and whether loss of both forms of the PRLR are important in this regard.

\section{Materials and Methods}

\section{Experimental design}

Ontogeny of UCP1 and PRLR Nineteen Bluefaced Leicester $\times$ Swaledale multiparous ewes of similar age, weight and body condition score were entered into the study. All ewes were fed to meet fully their requirements for both gestational age and fetal number. Perirenal adipose tissue (which constitutes $\sim 80 \%$ of adipose tissue in a newborn lamb) and livers were sampled from near term (145 days gestation; term $=148$ days) fetuses $(n=4)$ and lambs born normally at term were sampled at $6 \mathrm{~h}$ $(n=5)$, and at $7(n=5)$ and 30 days $(n=5)$ of life, following euthanasia.

Postnatal administration of PRL Weight-matched twin offspring of 24 Bluefaced Leicester $\times$ Swaledale ewes that were all born normally at term were entered into the study. A summary of the animal numbers used, postnatal ages and protocol groups is given in Table 1. Lamb pairs were randomised to inclusion in the acute or chronic studies. In the acute study, a lamb from each twin pair was randomly assigned to receive the pituitary extract PRL while its sibling received vehicle alone; pairs of lambs $(n=7)$ were subjected to euthanasia $2 \mathrm{~h}$ after PRL or vehicle administration in order to enable tissue sampling. For the chronic study, one lamb from each twin pair was randomly assigned to receive the pituitary extract PRL, or
S179D PRL, while its sibling received vehicle alone and tissue sampling was performed on day $7(n=14)$. A further three twin pairs of 22- to 24-day-old lambs had either S179D or vehicle administered daily for 6 days followed by tissue sampling as outlined above.

Jugular vein catheters were inserted into each pair of lambs under local anaesthetic ( $2 \%$ xylocaine) to enable administration of a daily bolus of pituitary extract PRL, S179D or vehicle. Once daily, at around $0900 \mathrm{~h}$ immediately prior to hormone or vehicle administration, blood sampling was undertaken. Colonic temperature was recorded prior to the hormone or vehicle administration and serially throughout the acute study and on days 2 and 6 for the chronic study. Unmodified pituitary extract PRL (2 mg ovine PRL per day; $n=15$; Sigma) or S179D PRL (10 $\mu \mathrm{g}$ per day; $n=6$ ) were dissolved in $1 \mathrm{ml} \mathrm{PBS,} \mathrm{pH} 7 \cdot 4$. The S179D PRL was prepared and characterised as previously described (Chen et al. 1998). Briefly, this entails expression in Escherichia coli, purification of inclusion bodies, solubilization, refolding and bioassay for activity. During the course of more than 20 clearance analyses performed on adult rats, there was no evidence of pyrogenic activity. Clearances of unmodified PRL and S179D PRL are very similar (Yang et al. 2001). Further confirmation that the pituitary extract PRL had no pyrogenic contaminants was obtained from the finding that it had no effect on colonic temperature when administered to juvenile sheep $(n=10)$ at the same dose as adopted in the present study. All operative procedures and experimental protocols had the required Home Office approval as designated by the Animals (Scientific Procedures) Act (1986).

\section{Protein analysis}

Crude plasma membrane and mitochondrial fractions were separately prepared from $1 \mathrm{~g}$ of frozen adipose, hepatic or uterine tissue (Budge et al. 2000). The protein content of each preparation was determined (Lowry et al. 1951) and UCP1 was detected in mitochondrial preparations following loading of equal amounts of protein and separation by SDS-PAGE using immunoblotting with enhanced chemiluminescence (ECL, Amersham). The antibody used was raised against purified ovine UCP1 (Schermer et al. 1996). Densitometric analysis was performed on all membranes following image detection using a Fuji film LAS-1000 cooled charge-coupled device (CCD) camera (Fuji Photo Film Co. Ltd, Tokyo, Japan). All gels were run in duplicate and a reference sample (i.e. from either adipose or hepatic tissue of a 6-h-old sheep) included on each gel. Confirmation that equal amounts of protein were transferred from each gel to membrane prior to immunodetection was obtained by Ponceau red staining of all membranes (Bispham et al. 1999). The thermogenic potential of mitochondria was also determined using $\left[{ }^{3} \mathrm{H}\right]$ GDP (Symonds et al. 1992). 
PRLR abundance in plasma membranes was detected on $6 \mu \mathrm{g}$ protein, using immunoblotting as described above for UCP1, utilising polyclonal antibodies R122 and R133 (Nevalainen et al. 1996) that specifically recognise the distinct intracellular regions of the differentially spliced long and short forms of PRLR respectively (Bispham et al. 1999). These antibodies detect a range of different molecular weight isoforms of each form of the PRLR which have been interpreted as representing altered extracellular domains of the receptor (Nevalainen et al. 1996, Budge et al. 2000). Specificity of binding was confirmed using non-inmmune rabbit serum. Using these antibodies, we have also found that some tissues (including the adrenal, brain, lung, mammary gland and placenta) only possess a single isoform of both the long and short form of PRLR (results not shown). This result suggests that the range of isoforms detected in adipose and hepatic tissue is not an artefact of tissue extraction but, in fact, indicates specifically processed forms.

\section{Metabolite and hormone analysis}

Plasma concentration of non-esterified fatty acids (NEFA) was measured enzymatically (Clarke et al. 1994) and plasma PRL was measured by RIA (McMillen et al. 1987, Budge et al. 2003). Briefly, all samples were assayed in duplicate following a 1:10 and 1:50 dilution using a rabbit anti-ovine prolactin primary antibody, iodinated ovine prolactin and goat anti-rabbit secondary antibody. The reagents used for the PRL assay, including iodination of PRL, were provided by Dr A F Parlow and the National Hormone and Pituitary Program of the National Institute of Diabetes and Digestive and Kidney Diseases (NIDDK). The intra- and inter-assay coefficients of variation were 3 and $9 \%(n=5)$ respectively.

\section{Statistical analysis}

All statistical evaluations were performed using SPSS 9.0 for Windows. Analysis of the effect of PRL on tissue measurements at each sampling age and differences with respect to developmental age were performed using the Mann-Whitney $U$ test. Other analyses were carried out using the General Linear Model procedure with correction for repeated measures. Linear correlations between potentially independent variables were described by Spearman's rank correlation coefficient. All values presented are means with their standard errors.

\section{Results}

Postnatal ontogeny of PRLR abundance

There was a marked divergence in the abundance of each isoform of PRLRs between adipose and hepatic tissues, as illustrated in Figs 1 and 2. In perirenal adipose tissue, the most abundant isoforms for the long form of PRLR were detected at 15, 29 and $60 \mathrm{kDa}$ compared with 45 and $51 \mathrm{kDa}$ for the short form (Fig. 1). For the liver, distinct isoforms for the long form of PRLR were present at 52 and $63 \mathrm{kDa}$ compared with 35 and $40 \mathrm{kDa}$ for the short form of PRLR. Within adipose tissue, the amounts of all forms of PRLRs decreased between postnatal ages 0.3 and 30 days; whereas in the liver, the long form remained largely unchanged and the short form increased (Fig. 2). These major changes in abundance additionally attest to the specificity of staining during the immunoblotting procedure. Furthermore, these adaptations occurred despite no change in total plasma membrane protein in adipose tissue with postnatal age (data not shown). Therefore, although there is an increase in adipocyte volume with age, in line with the increase in total fat mass, total membrane protein remains constant. Taken together these results indicate that the loss of PRLR with age in adipose tissue does not merely reflect a loss of adipocyte protein but is a real adaptation. There was a small decrease in plasma PRL between 144-days gestation and $6 \mathrm{~h}$ after birth followed by a return to previous levels at 4 days of age and no further change through one month of age (144-days gestation, $49 \cdot 6 \pm 0.6 \mathrm{ng} / \mathrm{ml} ; \quad 6 \mathrm{~h}, \quad 41 \cdot 5 \pm$ $0 \cdot 3 \mathrm{ng} / \mathrm{ml} ; 4$ days, $49 \cdot 4 \pm 1 \cdot 7 \mathrm{ng} / \mathrm{ml} ; 30$ days, $50 \cdot 4 \pm$ $1 \cdot 4 \mathrm{ng} / \mathrm{ml}$; (144 days vs $6 \mathrm{~h}, 6 \mathrm{~h}$ vs 4 days, $P<0 \cdot 05)$ ).

Adipose tissue When all time points were considered, the abundance of all isoforms of the long and short forms of PRLR significantly increased $(P<0.05)$ after 144 -days gestation to peak within $6 \mathrm{~h}(0 \cdot 3$-days postnatal age) after birth and then declined up to 30 days of age (Fig. 1). This transition was accompanied by a loss of UCP 1 by 30 days (Fig. 3) and an increase in the weight of perirenal adipose tissue $(6 \mathrm{~h}, \quad 20.9 \pm 5.5 \mathrm{~g} ; \quad 30$ days, $158 \cdot 3 \pm 13.4 \mathrm{~g}$; $P<0 \cdot 01)$. Throughout the study period, the abundance of UCP1 and each isoform of both the long and short forms of PRLR were positively correlated $\left(r^{2}, 0 \cdot 78-0 \cdot 94\right.$; $P<0 \cdot 01)$.

Hepatic tissue The abundance of all isoforms of the short form of PRLR declined between 144-days gestation and $6 \mathrm{~h}$ after birth. The decline in PRLR between 144-days gestation and $6 \mathrm{~h}$ after birth was significant with respect to the $40 \mathrm{kDa}$ isoform (Fig. 2b), but not the $35 \mathrm{kDa}$ isoform, and, thereafter, the abundance of the short form of PRLR increased to one month of age. A similar postnatal reduction was observed with respect to the long form of PRLR although in this case these changes were only significant for the $52 \mathrm{kDa}$ isoforms (Fig. 2a), with the abundance of the long form of PRLR remaining unchanged up to one month of age. Liver weight remained unchanged between 144-days gestation and 7 days after birth before doubling by one month of age (144-days gestation, $102 \cdot 0 \pm 10 \cdot 7 \mathrm{~g}$; 30 days, $209 \cdot 1 \pm 10 \cdot 3 \mathrm{~g} ; P<0 \cdot 001)$. 
(a)
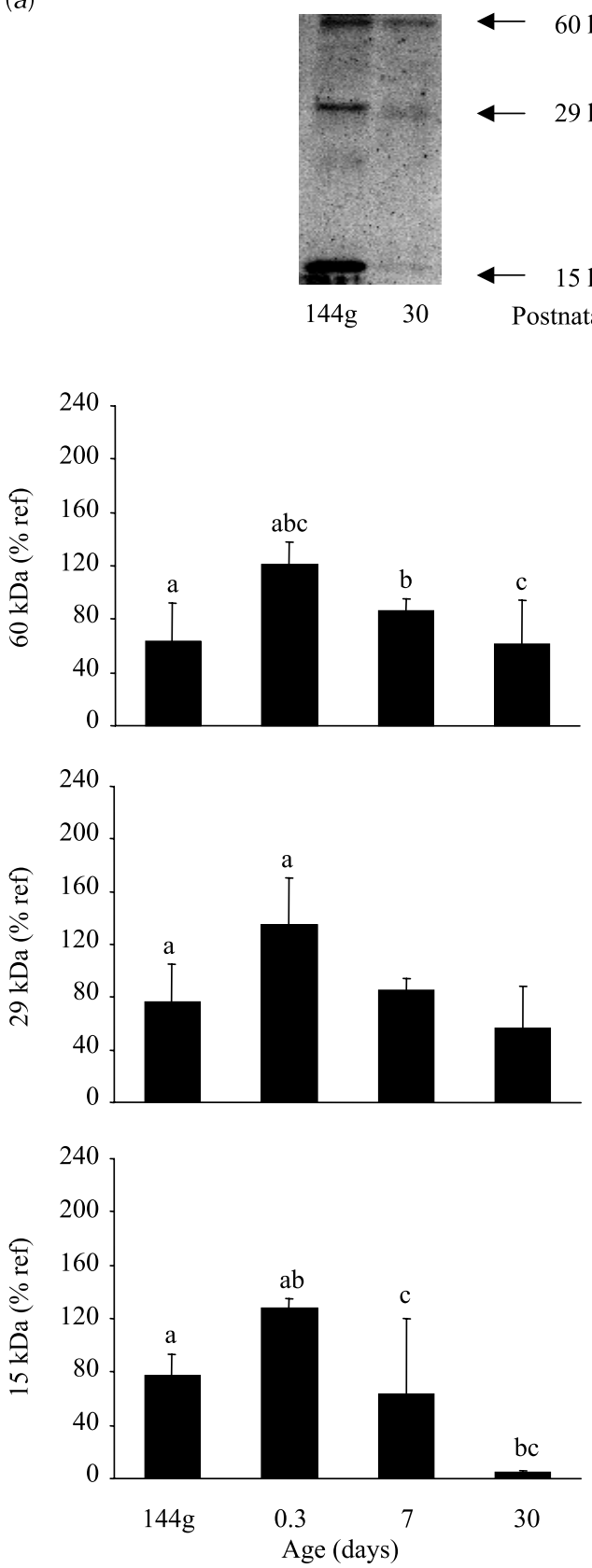

(b)
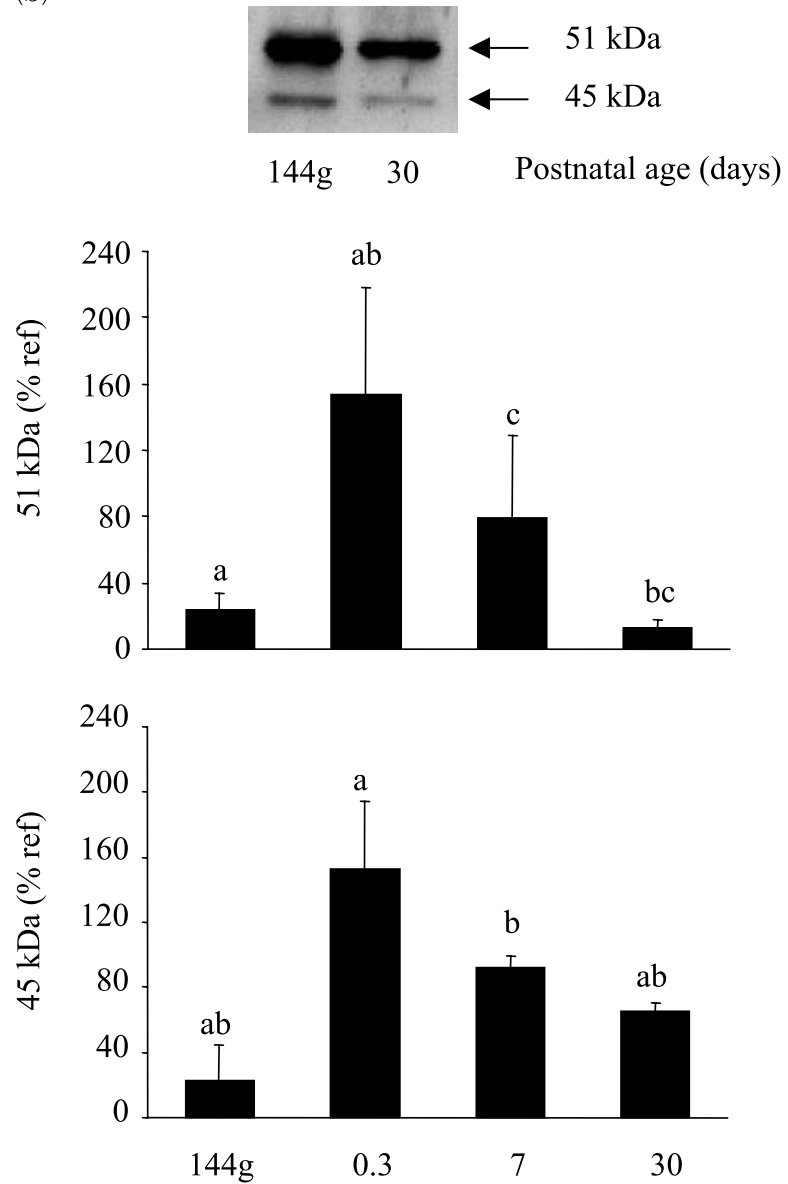

Age (days)

Figure 1 Ontogeny of PRLR abundance in adipose tissue in the near-term fetus and postnatal sheep. Mean densitometric analysis for (a) the long form of PRLR with specific isoforms at 15, 29 and $60 \mathrm{kDa}$, and (b) the short form of PRLR with specific isoforms at 45 and $51 \mathrm{kDa}$ between 144-days gestation (144g) and 30 days after birth in perirenal adipose tissue in sheep. An example of a CCD camera image showing abundance of long and short forms of PRLR shortly after birth and at 30 days of age is included. Identical amounts of protein (i.e. $6 \mu \mathrm{g}$ ) were loaded onto the gel for all samples. Values are means + s.E. and are expressed as a percentage of a reference sample included on all gels, $n=4-5$ per time point. Significant changes with age are indicated by identical lower-case letters: $a, b$ or $c, P<0 \cdot 05$.

Effect of PRL on thermoregulation and brown adipose tissue function

Following acute administration of unmodified pituitary extract PRL to 1-day-old sheep, a significant increase in colonic temperature occurred that peaked at 40-60 min post PRL administration $(P<0 \cdot 05)$ and was not observed in controls (Fig. 4). Shivering was not observed in any lambs over this time period. There was no difference in 

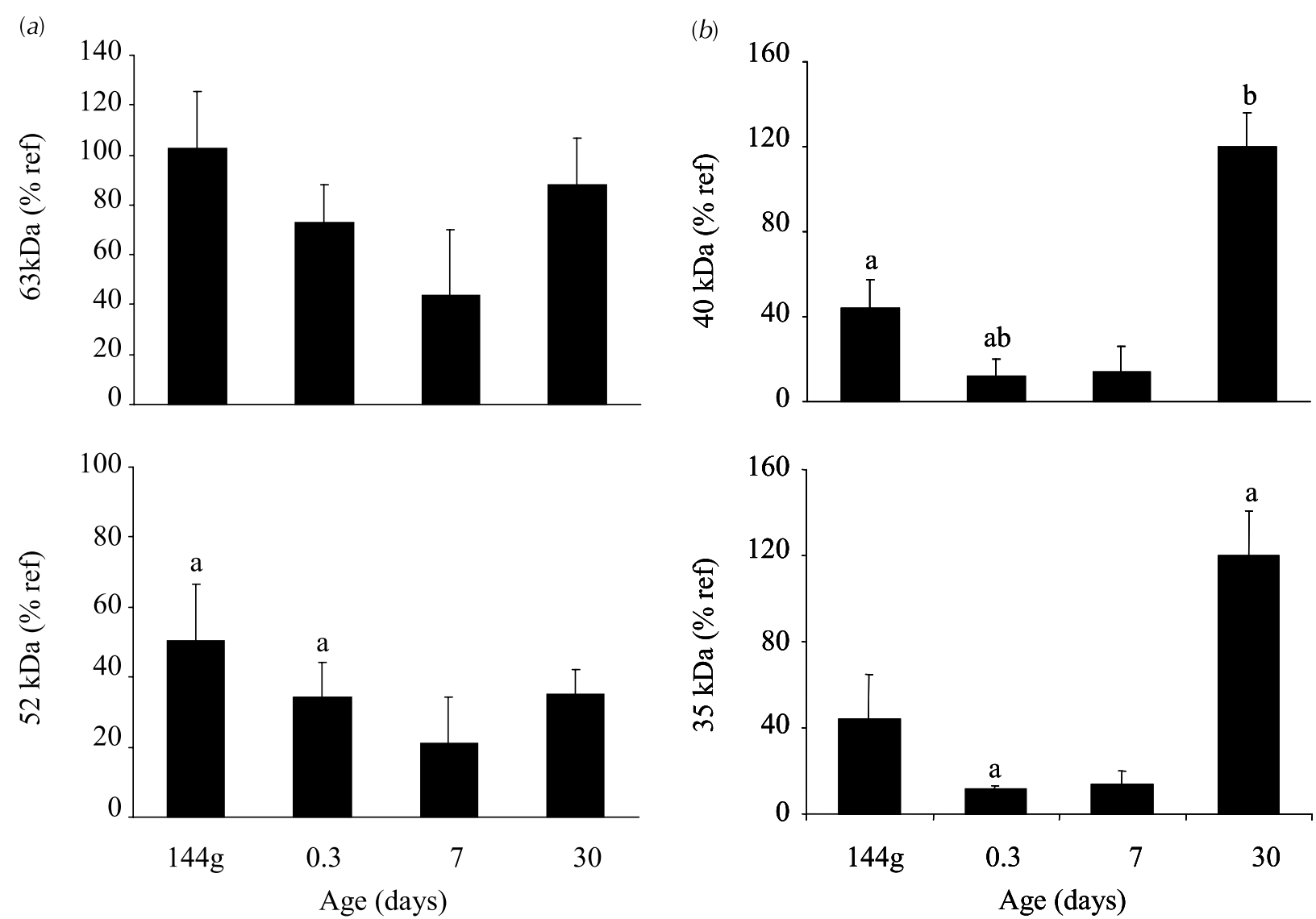

Figure 2 Ontogeny of PRLR abundance in hepatic tissue the near-term fetus and postnatal sheep. Mean densitometric analysis for (a) the long form of PRLR with a specific isoform at 52 and $63 \mathrm{kDa}$, and $(b)$ the short form of PRLR with a specific isoform at 35 and $40 \mathrm{kDa}$, between 144-days gestation $(144 \mathrm{~g})$ and 30 days after birth, in the liver in sheep. Identical amounts of protein (i.e. $6 \mu \mathrm{g}$ ) were loaded onto the gel for all samples. Values are means + S.E. and are expressed as a percentage of a reference sample included on all gels, $n=4-5$ per time point. Significant changes with age are indicated by identical lower-case letters: a or $b, P<0 \cdot 05$.

UCP1 abundance or thermogenic potential between groups (Table 2). PRL-administered lambs showed a greater rise in plasma NEFA when measured in samples taken immediately prior to PRL injection and $2 \mathrm{~h}$ after PRL administration (control, $0 \cdot 13 \pm 0 \cdot 01$; PRL, $0 \cdot 51 \pm$ $0.12 \mathrm{mmol} / \mathrm{l} ; P<0 \cdot 05)$.

The dose of unmodified pituitary extract PRL used in our chronic study resulted in a threefold increase in PRL (pre-PRL, $47 \cdot 6 \pm 0.6 \mathrm{ng} / \mathrm{ml}$; post-PRL, $240 \cdot 5 \pm 3.5 \mathrm{ng} /$ $\mathrm{ml} ; P<0 \cdot 001)$ that was maintained over the 6-day duration. Administration of S179D PRL resulted in an acute rise in colonic temperature at both 2 and 6 days of age (Fig. 5). Following repeated administration of pituitary extract PRL, the normal decline in colonic temperature between 1 and 2 days of age was delayed (Fig. 6). After this time, temperature was similar between groups. On day 7 , although there was no difference in UCP1 abundance between PRL-administered groups, its thermogenic potential was higher in lambs receiving PRL (Table 2).
Both mixed PRL and S179D PRL caused a persistent increase in plasma NEFA, although this was only statistically significant on day 4 , irrespective of whether lambs were given PRL or S179D PRL (control, 0.24 $\pm 0 \cdot 33$; PRL, $1 \cdot 87 \pm 0.30 \mathrm{mmol} / \mathrm{l} ; P<0 \cdot 05)$.

In the older sheep, which had S179D PRL administered from 22 days of age, there was no change in colonic temperature in response to PRL (pre-S179D PRL, $39 \cdot 01 \pm 0 \cdot 72{ }^{\circ} \mathrm{C}$; post-S179D PRL, $\left.39 \cdot 21 \pm 0 \cdot 60^{\circ} \mathrm{C}\right)$. UCP1 was undetectable in mitochondria prepared from these animals and the thermogenic potential $(15 \cdot 1 \pm 1$ pmol per $\mathrm{mg}$ of mitochondrial protein) and plasma NEFA $(0 \cdot 12 \pm 0.01 \mathrm{mmol} / \mathrm{l})$ remained low and were similar to vehicle-injected controls. In addition to demonstrating the effect of age on the thermogenic response to PRL, these experiments demonstrate that the newborn thermogenic response was very unlikely to be a pyrogenic one, especially since pyrogenic responses increase with age (Coceani et al. 1995). 

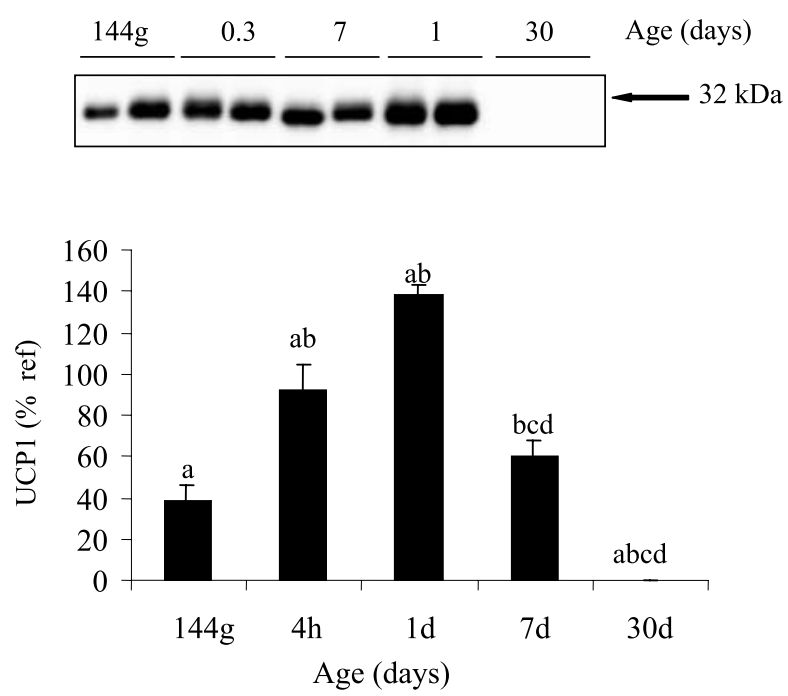

Figure 3 Ontogeny of UCP1 abundance in adipose tissue in the near-term fetus and postnatal sheep. Example of a CCD camera image showing abundance of UCP1 between 144-days gestation (144g) and 30 days after birth in perirenal adipose tissue in sheep. Identical amounts of protein (i.e. $10 \mu \mathrm{g}$ ) were loaded onto the gel for all samples. Values are means + s.E. and are expressed as a percentage of a reference sample included on all gels, $n=4-5$ per time point. Significant changes with age are indicated by identical lower-case letters: $a, P<0 \cdot 05$; b or $c, P<0 \cdot 012 ; d, P<0 \cdot 001$.

\section{Discussion}

Our major findings are that the disappearance of UCP1 from adipose tissue after birth is very closely correlated with loss of both forms of the PRLR. This postnatal adaptation appears to be specific to brown adipose tissue, as there is little change after birth in the abundance of the PRLR in the liver, a tissue that does not possess any

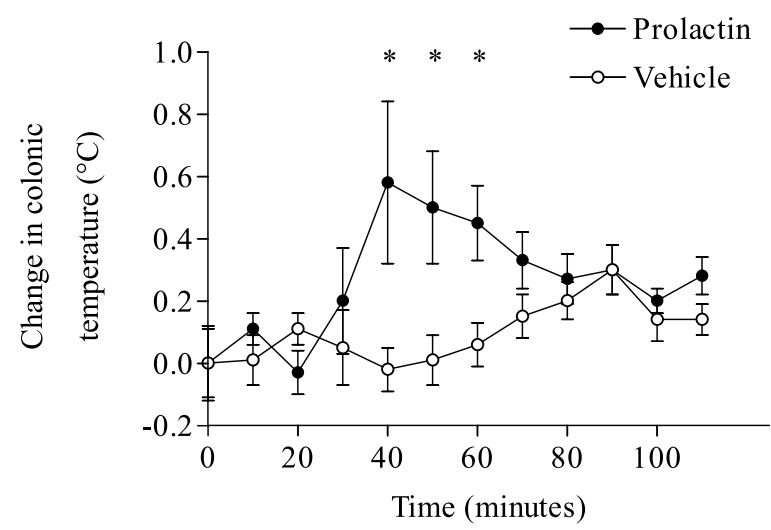

Figure 4 Effect of a single administration of pituitary extract PRL ( $2 \mathrm{mg}$ ) on the change in colonic temperature from baseline in 1-day-old sheep. Values are presented as means \pm S.E;

-, PRL-treated lambs; $O$, control (vehicle-treated) lambs; $n=5$ per group. ${ }^{*} P<0 \cdot 05$, significant differences between groups at the same time point. mitochondrial UCPs (Arsenijevic et al. 2000). Furthermore, we have shown that administration of either pituitary extract PRL containing a mixture of posttranslationally modified forms or its pseudophosphorylated form (S179D PRL) can elicit a thermogenic effect in neonatal sheep at a time when UCP1 abundance is near maximal.

The differential postnatal ontogeny of the PRLR between adipose and hepatic tissue

The finding of a range of different isoforms for the PRLR in adipose tissue and in the liver is in accord with similar findings in the growing fetus (Budge et al. 2000). It is also in agreement with other studies in the bovine species in which the abundance of different isoforms of the PRLR has been found to vary greatly between tissues (Schuler et al. 1997). Whether one, or more, isoforms of each form of the PRLR may have a preferential role in regulating tissue metabolism and, in particular, mitochondrial function remains to be elucidated but the parallel changes in all forms suggest that it is the overall level of receptor that is crucial and not processing to one particular form. Interestingly, the peak in PRLRs immediately following parturition appears to be specific to brown adipose tissue since, in the liver, PRLR abundance was higher immediately before, compared with after, birth. Although PRL has the potential to promote UCP1 abundance in the late-gestational fetus and neonate (Budge et al. 2002), a reduction in plasma hormone concentrations (other than PRL), may also act to promote the loss of both PRLR and UCP1 in the postnatal sheep, as there was only a modest fluctuation in plasma PRL at this time.

\section{The phosphorylation of $P R L$ and its biological activity}

One critical factor in determining the thermogenic effect of PRL appears to be the amount of phosphorylated PRL rather than the total amount of PRL, as the same magnitude of effect was observed using $2 \mathrm{mg}$ of mixed PRL and $10 \mu \mathrm{g}$ of the S179D form. Pituitary extract PRL (2 mg) administered once per day resulted in an increase in plasma PRL equivalent to that reported under long-day conditions (Bassett et al. 1989, Taylor et al. 2000), but the amount of PRL used in the present study was probably in excess of need. It is unlikely, therefore, that S179D PRL is 200-fold the potency of pituitary extract PRL. S179D PRL and naturally phosphorylated PRL have, however, been shown to be several-fold more potent than unmodified and mixed PRL for some activities (Wang \& Walker 1993, Chen et al. 1998, Kuo et al. 2002). Based on dosage and clearance studies in rats (Yang et al. 2001) and the concentration of endogenous PRL in the lambs, it is estimated that the S179D PRL was at least 5 times more potent than the pituitary extract PRL. Two-dimensional gel analysis of ovine pituitary PRL has shown the presence 
Table 2 Effect of acute and chronic administration of pituitary extract PRL on the abundance and thermogenic potential of UCP1 in postnatal sheep

\begin{tabular}{|c|c|c|c|c|}
\hline & \multicolumn{2}{|l|}{ Day 1} & \multicolumn{2}{|l|}{ Day 7} \\
\hline & Vehicle $(n=7)$ & $\operatorname{PRL}(n=7)$ & Vehicle $(n=8)$ & $\operatorname{PRL}(n=8)$ \\
\hline UCP1 abundance (\% ref) & $102 \pm 4$ & $102 \pm 3$ & $53 \pm 9$ & $55 \pm 10$ \\
\hline $\begin{array}{l}\text { Thermogenic potential } \\
\text { (pmol per mg of } \\
\text { mitochondrial protein) }\end{array}$ & $57 \pm 7$ & $62 \pm 6$ & $17 \pm 1$ & $38 \pm 2^{*}$ \\
\hline
\end{tabular}

${ }^{*} P<0 \cdot 05$, significant differences between PRL and vehicle-administered groups at the same postnatal age.

of all forms of the hormone and ashing analysis has found some preparations to contain as much as $20 \%$ phosphorylated PRL (Arumburo et al. 1992).

(a)

Day 2

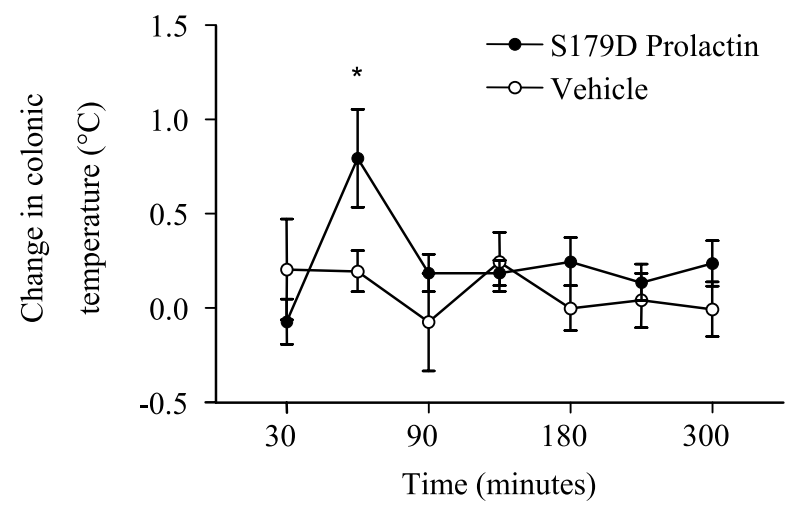

(b)

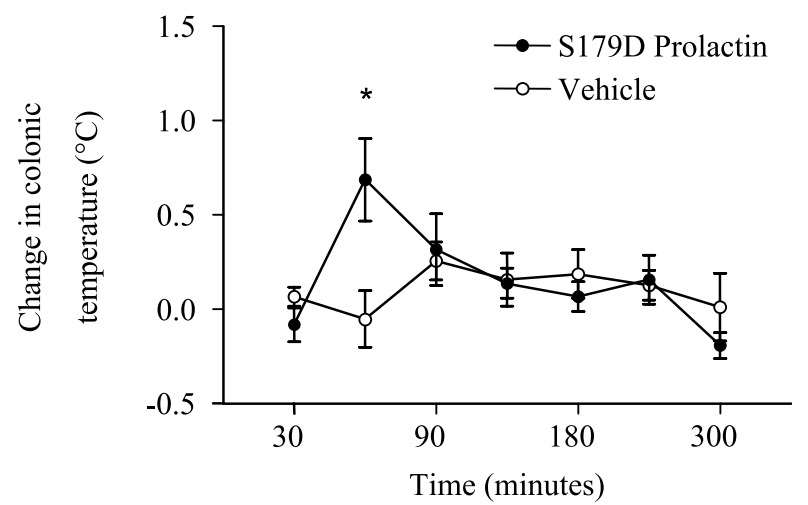

Figure 5 Effect of daily administration of S179D PRL on acute changes in colonic temperature in neonatal sheep at (a) 2 days and $(b) 6$ days after birth. Values are presented as means \pm S.E;

๑, S179D PRL-treated sheep; $\bigcirc$, control (vehicle-treated) lambs; $n=5$ per group. ${ }^{*} P<0 \cdot 05$, significant differences between groups at the same time point.
Although S179D PRL has been shown to be an antagonist to the growth-promoting effects of unmodified PRL (Chen et al. 1998, Xu et al. 2001), it can act as a super agonist in regard to tissue-specific PRL-regulated activities (e.g. Kuo et al. 2002, Xu et al. 2002). The effect of S179D PRL in brown adipose tissue is, therefore, consistent with promotion of tissue-specific activities unrelated to growth. This may explain why S179D PRL, but not the native hormone, elicited a thermogenic effect at both 2 and 6 days after birth. An acute thermoregulatory response to PRL was observed in the absence of an increase in the amount or thermogenic potential of UCP1. It was not, however, accompanied by any occurrence of shivering which is indicative of improved thermal efficiency that would enable a rise in body temperature (Clarke et al. 1996). With prolonged exposure to either pituitary extract PRL or S179D PRL, an increase in lipolysis occurred in conjunction with a rise in the thermogenic potential of UCP1. These adaptations occurred over the period in which plasma NEFA and UCP1 abundance normally decline (Clarke et al. 1997b), thereby indicating that PRL is able to delay these responses. In sheep, which lose UCP1 soon after birth (Clarke et al. 1997b), the presence

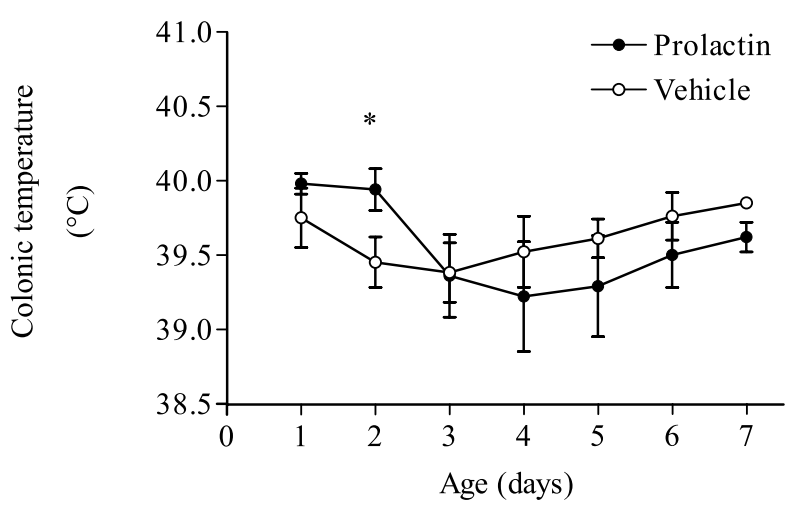

Figure 6 Effect of repeated once-daily administration of pituitary extract PRL ( $2 \mathrm{mg}$ per day) on colonic temperature in neonatal sheep. Values are presented as means \pm S.E; $\bullet$, S179D PRL-treated animals; $\bigcirc$, controls (vehicle-treated); $n=5$ per group. ${ }^{*} P<0 \cdot 05$, significant differences between groups at the same time point. 
of large amounts of functional brown adipose tissue in the perinatal period determines the animal's sensitivity to PRL as no effect on colonic temperature or UCP1 function was found in older lambs.

\section{Developmental effects of PRL on brown adipose tissue function}

The appearance of a refractory period to further endocrine stimulation with PRL in the chronic PRL study is in accord with the effect of exogenous leptin, which likewise only promotes body temperature over the first 2 days after birth (Mostyn et al. 2002). It is possible that the loss of responsiveness after the second day of life may be related in part to the decrease in plasma catecholamines and parallel decline in $\beta$-adrenergic adrenoreceptors (Casteilla et al. 1994). In contrast to the previously described effects of leptin (Mostyn et al. 2002), whose receptor is also a member of the class I cytokine superfamily, PRL had no effect on promoting the loss of UCP1 over the first week of life. In view of the parallel loss of PRLR and UCP1, it appears that factors regulating PRLR abundance may be important in determining the transition of adipose tissue from brown to white characteristics. An ability to delay this adaptation could have a beneficial role in preventing excess adipose tissue deposition in later life since transgenic mice lacking UCP1 subsequently go on to develop obesity (Lowell et al. 1993). Postnatal stimulation of PRLR abundance could be used to retain UCP1 as, for example, enhanced abundance of the long form of PRLR and UCP1 have been found in the fetus following augmented maternal nutrition in late gestation (Budge et al. 2000).

In conclusion, we have demonstrated a close relationship between the tissue-specific ontogeny of UCP and the PRLR. At the same time, PRL, and particularly the molecular mimic of phosphorylated PRL, can act as a thermogenic hormone over the first few days of postnatal life, during which time there is a very close relationship between the loss of UCP1 from brown adipose tissue and ontogenic changes in PRLRs. Taken together, our findings suggest a potential role for PRL and the PRLR in the regulation of UCP expression and function.

\section{Funding}

S P was supported by a Biotechnology and Biological Sciences Research Council Studentship, A M by a University of Nottingham Postgraduate Scholarship and E G by a Wellcome Trust Vacation Scholarship. A M W was supported by NIH grant DK 61005. The authors declare that there is no conflict of interest that would prejudice the impartiality of this scientific work.

\section{References}

Arsenijevic D, Onuma H, Pecquer C, Raimbault S, Manning BS, Miroux B, Couplan E, Alves-Guerra M-C, Goubern M, Surwit R,
Bouillaud F, Richard D, Collins S \& Ricquier D 2000 Disruption of the uncoupling protein-2 gene in mice reveals a role in immunity and reactive oxygen species production. Nature Genetics 26 435-439.

Arumburo C, Monteil JL, Proudman JA, Berghman LR \& Scanes CG 1992 Phosphorylation of prolactin and growth hormone. Journal of Molecular Endocrinology 8 183-191.

Bassett JM, Curtis N, Hanson C \& Weeding CM 1989 Effects of altered photoperiod or maternal melatonin administration on plasma prolactin concentrations in fetal lambs. Journal of Endocrinology 122 633-643.

Bignon C, Binart N, Ormandy C, Schuler LA, Kelly PA \& Dijane J 1997 Long and short forms of the ovine prolactin receptor: cDNA cloning and genomic analysis reveal that the two forms arise by different alternative splicing mechanisms in ruminants and rodents. Journal of Molecular Endocrinology 19 109-120.

Bispham JR, Heasman L, Clarke L, Ingleton PM, Stephenson T \& Symonds ME 1999 Effect of maternal dexamethasone treatment and ambient temperature on prolactin receptor abundance in brown adipose and hepatic tissue in the fetus and newborn lamb. Journal of Neuroendocrinology 11 849-856.

Budge H, Bispham J, Dandrea J, Evans L, Heasman L, Ingleton P, Sullivan C, Wilson V, Stephenson T \& Symonds ME 2000 Effect of maternal nutrition on brown adipose tissue and prolactin receptor status in the fetal lamb. Pediatric Research 47 781-786.

Budge H, Mostyn A, Wilson V, Khong A, Walker AM, Symonds ME \& Stephenson T 2002 The effect of maternal prolactin infusion during pregnancy on fetal adipose tissue development. Journal of Endocrinology 147 427-433.

Budge H, Dandrea J, Mostyn A, Evens Y, Watkins R, Sullivan C, Ingleton P, Stephenson T \& Symonds ME 2003 Differential effects of fetal number and maternal nutrition in late gestation on prolactin receptor abundance and adipose tissue development in the neonatal lamb. Pediatric Research 53 302-308.

Casteilla L, Champigny O, Muzzin P, Bouillaud F, Robelin J \& Ricquier D 1994 Expression of $\beta_{1}$ - and $\beta_{3}$-adrenergic-receptor messages and adenylate cyclase $\beta$-adrenergic response in bovine perirenal adipose tissue during its transformation from brown into white fat. Biochemical Journal 297 93-97.

Chen T-J, Kuo BK, Tsai KF, Liu J-W, Chen D-Y \& Walker AM 1998 Development of recombinant human prolactin receptor antagonists by molecular mimicry of the phosphorylated hormone. Endocrinology 139 609-616.

Clarke L, Darby CJ, Lomax MA \& Symonds ME 1994 Effect of ambient temperature during 1 st day of life on thermoregulation in lambs delivered by cesarean section. Journal of Applied Physiology $\mathbf{7 6}$ $1481-1488$

Clarke L, Bird JA, Lomax MA \& Symonds ME 1996 Effect of $\beta_{3}$-adrenergic agonist (Zeneca D7114) on thermoregulation in near-term lambs delivered by cesarean section. Pediatric Research $\mathbf{4 0}$ 330-336.

Clarke L, Bryant MJ, Lomax MA \& Symonds ME 1997a Maternal manipulation of brown adipose tissue and liver development in the ovine fetus during late gestation. British Journal of Nutrition 77 871-883.

Clarke L, Buss DS, Juniper DS, Lomax MA \& Symonds ME $1997 b$ Adipose tissue development during early postnatal life in ewe-reared lambs. Experimental Physiology 82 1015-1017.

Clarke L, Heasman L, Firth K \& Symonds ME 1997c Influence of route of delivery and ambient temperature on thermoregulation in newborn lambs. American Journal of Physiology 272 R1931-R1939.

Coceani F, Bishai I, Engelberts D, House RV \& Adamson SL 1995 Response of newborn and adult sheep to pyrogens: relation between fever and brain eicosanoid changes. Brain Research $\mathbf{7 0 0}$ 191-204.

Goffin V, Binart N, Clement-Lacroix P, Bouchard B, Bole-Feysot C, Edery M, Lucas BK, Touraine P, Pezet A, Maaskant R, Pichard C, Helloco C, Baran N, Favre H, Bernichtein S, Allamando A, 
Ormandy C \& Kelly PA 1999 From the molecular biology of prolactin and its receptor to the lessons learned from knockout mice models. Genetic Analysis: Biomolecular Engineering 15 189-201.

Houghton DC, Young IR \& McMillen IC 1995 Response of prolactin to different photoperiods after surgical disconnection of the hypothalamus and pituitary in sheep fetuses. Journal of Reproduction and Fertility 104 199-206.

Kuo CB, Wu W, Xu X, Yang L, Chen C, Coss D, Birdsall B, Nasseri D \& Walker AM 2002 Pseudophosphorylated prolactin (S179D PRL) inhibits growth and promotes beta-casein gene expression in the rat mammary gland. Cell and Tissue Research 309 429-437.

Lowell BB, S-Susulic V, Hamann A, Lawitts JA, Himms-Hagen J, Boyer BB, Kozak LP \& Flier JS 1993 Development of obesity in transgenenic mice after genetic ablation of brown adipose tissue. Nature 366 740-742.

Lowry OH, Rosenbrough NJ, Farr AL \& Randall RJ 1951 Protein measurement with the Folin phenol reagent. Journal of Biological Chemistry 193 265-275.

McMillen IC, Thorburn GD \& Walker DW 1987 Diurnal variations in plasma concentrations of cortisol, prolactin, growth hormone and glucose in the fetal sheep and pregnant ewe during late gestation. Journal of Endocrinology 114 65-72.

McMillen IC, Houghton DC \& Phillips ID 2001 Maturation of cytokine-receptors in preparation for birth. Biochemical Society Transactions $2963-68$.

Mostyn A, Bispham J, Pearce S, Evens Y, Raver N, Keisler DH, Webb R, Stephenson T \& Symonds ME 2002 Differential effects of leptin on thermoregulation and uncoupling protein abundance in the neonatal lamb. FASEB Journal 16 1438-1440.

Nevalainen M, Valve EM, Ingleton PM \& Harkonen PL 1996 Expression and hormone regulation of prolactin receptors in rat dorsal and lateral prostate. Endocrinology 137 3078-3088.

Phillips ID, Anthony RV, Houghton DC \& McMillen IC 1999 The regulation of prolactin receptor messenger ribonucleic acid levels in the sheep liver before birth: the relative roles of the fetal hypothalamus, cortisol and the external photoperiod. Endocrinology $1401966-1971$.

Schermer SJ, Bird JA, Lomax MA, Shepherd DAL \& Symonds ME 1996 Effect of fetal thyroidectomy on brown adipose tissue and thermoregulation in newborn lambs. Reproduction Fertility and Development 8 995-1002.
Schuler LA, Nagel RJ, Gao J, Horseman ND \& Kessler MA 1997 Prolactin receptor heterogeneneity in bovine fetal and maternal tissues. Endocrinology 138 3187-3194.

Symonds ME, Andrews DC \& Johnson PJ 1989 The control of thermoregulation in the developing lamb during slow wave sleep. Journal of Developmental Physiology 11 289-298.

Symonds ME, Bryant MJ, Clarke L, Darby CJ \& Lomax MA 1992 Effect of maternal cold exposure on brown adipose tissue and thermogenesis in the neonatal lamb. Journal of Physiology, London 455 487-502.

Symonds ME, Phillips ID, Anthony RV, Owens JA \& McMillen IC 1998 Prolactin receptor gene expression and foetal adipose tissue. Journal of Neuroendocrinology 10 885-890.

Taylor K, Gray C, Joyce M, Stewart M, Bazer F \& Spencer T 2000 Neonatal ovine uterine development involves alterations in expression of receptors for estrogen, progesterone, and prolactin. Biology of Reproduction 63 1192-1204.

Wang YF \& Walker AM 1993 Dephosphorylation of standard prolactin produces a more biologically active molecule. Evidence for antagonism between non-phosphorylated and phosphorylated prolactin in the stimulation of $\mathrm{Nb} 2$ cell proliferation. Endocrinology 133 2156-2160.

Xu X, Kreye E, Kuo C \& Walker A 2001 A molecular mimic of phosphorylated prolactin markedly reduced tumor incidence and size when DU145 human prostate cancer cells were grown in nude mice. Cancer Research 139 609-616.

Xu X, Wu W, Williams V, Deng C, Khong A, Chen Y-H \& Walker A 2002 Opposite effects of unmodified PRL and a molecular mimic of phosphorylated PRL on morphology and the expression of prostate-specific genes in the normal rat prostate. Prostrate 54 25-33.

Yang L, Kuo CB, Liu Y, Coss D, Xu X, Chen C, Oster-Granite ML \& Walker AM 2001 Administration of unmodified prolactin (U-PRL) and a molecular mimic of phosphorylated prolactin (PP-PRL) during rat pregnancy provides evidence that the U-PRL:PP-PRL ratio is crucial to the normal development of pup tissues. Journal of Endocrinology 168 227-238.

Yang L, Lii S, Kuo B, Buckley A, Buckley D, Chen C, Xu X, Coss D \& Walker AM 2002 Maternal prolactin composisiton can permanently affect epidermal $\gamma \delta \mathrm{T}$ cell function in the offspring. Developmental and Comparative Immunology 26 849-860.

Received 19 October 2004

Accepted 29 October 2004 